\title{
Potential of Producing Hydrogen for Fuel-Cell Vehicles by Residential Fuel Cell Co-generation Utilizing Idle Capacity
}

\author{
Yusuke Ono, Takahide HanedA, Takashi IkEgAmi, and Atsushi AKISAWA ${ }^{\dagger}$ \\ (Received April 5, 2017)
}

\section{家庭用燃料電池システムの水素製造余力を用いた燃料電池自動車用水素製造可能性の評価 小野優輔，羽田貴英，池上貴志，秋澤 淳}

\begin{abstract}
Widespread of fuel-cell vehicles (FCV) is one of the essential solutions to $\mathrm{CO}_{2}$ emission mitigation. However there were only 81 working hydrogen stations distributed in Japan in January 2017. Therefore, it has become increasingly necessary to establish the hydrogen stations. In this study, we focus on the unutilized hydrogen production capacity of a fuel processor system (FPS) incorporated in a residential fuel cell co-generation system. We proposed a system which the FPS and fuel cell stacks are operated independently at their respective efficient load factors, and which can produce hydrogen for the FCV using the unutilized capabilities of the FPS. An optimum scheduling model for the operation of the FPS and the fuel cell stacks was developed to evaluate annual hydrogen production for the FCV for 24 households. As the results, it was found that all households have the capacity to produce at least $1,040 \mathrm{Nm}^{3}$ /year of hydrogen, which a FCV can run 8,000 km in a year. Furthermore, we evaluated the hydrogen supply potential of collective housings installed this system to each household through the case study in Tama region, Tokyo. In the case where this system was introduced to 10 collective housings in Tama region, it was found that $80.9 \%$ of hydrogen demand for FCV in this region in 2025 in this region could be supplied.
\end{abstract}

\section{Key Words}

Fuel-cell, Fuel processor system, hydrogen production

$\mathrm{CO}_{2}$ の排出削減に必要な解決策の一つとして, 燃料電池自動車 $(\mathrm{FCV})$ の普及が期待されている。しかし, 2017 年1月現在, 全国の水素ステーションは 81 ヶ所のみであり, 水素供給インフラ建設の必要性が増してきている。本研究では, 家庭用燃 料電池内部に組み込まれている改質器が持つ未活用の水素製造能力に注目した。改質器と燃料電池スタックがそれぞれの 効率の良い部分負荷率で独立に運転され, 改質器の余力を用いて FCV 用水素を製造するシステムを提案した。改質器と燃 料電池スタックの最適運転計画モデルを構築し，24 世帯を対象に FCV 用水素製造可能量を計算した。2 24 世帯すべてに おいて少なくとも年間 $8,000 \mathrm{~km}$ 走行分の水素 $1,040 \mathrm{Nm}^{3}$ を製造可能であることが分かった。さらに, 東京都多摩地区を 対象としたケーススタデイにより, 集合住宅の各世帯に本システムを導入した場合の水素供給ポテンシャルを評価した。多摩 地区内の 10 ケ所の集合住宅に本システムを導入した場合, 2025 年の FCVの普及目標に対して $80.9 \%$ FCVの水素需要 を満たすことができることが示された。

キーワード

燃料電池, 燃料改質器, 水素製造

Graduate School of Bio-Applications and Systems Engineering (BASE), Tokyo University of Agriculture and Technology 2-24-16 Nakacho, Koganei-shi, Tokyo 184-8588, Japan

† Corresponding author: akisawa@cc.tuat.ac.jp
東京農工大学大学院生物システム応用科学府

T 184-8588 東京都小金井市中町 2-24-16 


\section{1. 緒 言}

地球温暖化問題が懸念される近年, 二酸化炭素を排出し ないエコカーの一つである燃料電池自動車 (以下, FCV) が 注目を集めており，2020 年までに 4 万台，2025 年までに 25 万台, 2030 年までに 80 万台の FCV の普及が目標として揭 げられている1)。FCV の燃料として用いる高圧水素を供給す る水素ステーションは, 一定の品質で ${ }^{2)}$, 安全で確実に数 分程度で水素を充填するための設備 ${ }^{3)}$ が必要であり, 2017 年 1 月現在，全国で 81 ケ所 ${ }^{4)}$ のみである。2020 年までに 160 ヶ所, 2025 年度までに 320 ヶ所の水素ステーションの導 入という目標 ${ }^{1)}$ の達成に向けて, 水素供給インフラの充実は 喫緊の課題である。現状では水素は天然ガス等の炭化水素 の改質や副生水素によって賄われており，2030 年頃までは化 石燃料起源の水素が FCV に供給される見通しである1)。

また，家庭用の燃料電池コジェネレーションシステムは， 燃料電池スタックによる発電時の排熱を給湯に活用すること により高い総合エネルギー効率が得られ，低炭素な熱電併 給システムとして期待されている5)。家庭用燃料電池につい ては 2020 年に 140 万台, 2030 年に 530 万台という普及目標 が揭げられている11。

現在普及が進んでいる固体高分子形燃料電池 (PEFC： Polymer Electrolyte Fuel Cell, 以下，燃料電池）は，都市 ガスを燃料とし，水蒸気改質法により水素を製造する改質器 （FPS : Fuel Processing System）が内部に組み込まれている。 燃料電池は給湯負荷に追従して運転するため, 特に給湯需 要が少ない夏期及び染夜では運転を停止している時間が長 いことが知られており ${ }^{6)}$, 運転していない時間帯は改質器も 停止している。本研究では, この改質器が停止している時間 帯や, 燃料電池が部分負荷運転をしている際の改質器が定 格運転していない時間帯に注目し, 燃料電池内部の改質器 が持つ未活用の水素製造能力を利用して FCV 用の水素を製 造するシステムを提案する。家庭用燃料電池に付属の改質器 の余力を活用して水素製造を行うことにより, 水素ステーショ ンの普及が拡大するまでの FCV 用水素供給に一定の役割を 果たすことが期待できる。また，集合住宅等の多数の世帯 に設置された燃料電池が持つ水素製造能力を統合すること により, 地域内の多数の FCV に水素を供給することができ, 水素ステーションの役割を担うことも期待できる。なお，固 体酸化物形燃料電池 (SOFC : Solid Oxide Fuel Cell) につい ても既に普及が始まっているが，PEFC とは異なり，一酸化 炭素 (CO) も燃料として利用できることから，SOFCに付属 する改質器にはCO 除去装置が含まれていない。そのため, その改質器で製造された水素には多量の CO が含まれ，こ の水素を FCV 用燃料としてそのまま使用することは困難とな る。そこで本研究では, 改質器に予め CO 除去装置が備わっ ている PEFCを対象とした。

これまで, 家庭用燃料電池の導入効果を解析した研究と して, 熱電併給運転における経済性および環境性を定量的 に評価した研究は多数存在する5) 7)。また，電気自動車が 導入された住宅を対象にした燃料電池の導入効果の解析 ${ }^{8}$
や，複数の住宅を対象に，大規模な水素製造装置と各々の 住宅に純水素燃料電池が配置するシステムの最適化運用及 び導入効果を解析した研究も存在する ${ }^{9)}$ 10)。しかしながら, いずれの研究も固体高分子形燃料電池の機能は熱電併給に 限定されており，家庭用燃料電池によって FCV 用水素を製 造し，供給する，すなわち水素ステーション代替として機能 させることは検討されていない。

そこで本研究では, 固体高分子形燃料電池内部の改質器 の余力としての水素製造可能量を定量的に評価することを目 的とした。多様な給湯負荷特性を持つ複数の世帯を対象に したエネルギー需給シミュレーションを行い，固体高分子形 燃料電池の本来の利用目的である給湯との両立を図った最 適な改質器の運用手法を検討した。得られた世帯あたりの 年間水素製造可能量をもとに，集合住宅の各世帯に設置さ れている固体高分子形燃料電池に本システムを導入した場 合の, 地域の FCV 用水素需要に対する供給地域や FCV 台 数のカバー率について東京都多摩地区を対象に分析を行い, 水素ステーションの役割を担う能力を簡易的に評価した。

\section{2. 家庭用燃料電池による水素供給システム}

\section{1 提案する改質器独立型燃料電池システム}

燃料電池は，発電を行うと同時に，燃料電池スタックで生 じる熱を利用して温水を製造するシステムである。都市ガスを 改質して水素を製造する改質器, 燃料電池スタック, 温水を 蓄える貯湯槽で構成されている。燃料電池からの熱のみでは 給湯需要を賄えない時に備え, ガス給湯器も付属している ${ }^{11}$ 。 通常, 家庭用の燃料電池は, 燃料電池スタックで必要とな る分だけの水素を改質器で生成するため, 改質器と燃料電 池スタックは連動した負荷率で運転している。燃料電池ス タックは負荷率が低いほど発電効率が高く12), 反対に, 改 質器は負荷率が高いほど改質効率が高い13)ことが知られて いる。そのため, 燃料電池スタックは低負荷率で, 改質器 は高負荷率で独立して運転することで，これまでより効率的 な運用が可能となると考えられる。

本研究では, 燃料電池スタックと改質器の負荷率を独立 に設定できるシステムを提案し，改質器で製造された水素は 一旦貯蔵タンクに蓄えられ, 燃料電池スタックや FCV に充填 して用いるシステムについて検討した。

\subsection{FCV 用水素製造可能量の定量的評価}

本研究ではまず, 家庭用燃料電池の改質器の余力を用い た FCV 用水素の製造可能量を定量的に評価するため，燃料 電池と改質器を独立に運転する最適運転計画モデルを開発 し，エネルギー需給シミュレーションを行った。

作成したエネルギー需給シミュレーションモデルの詳細は 第 3 章で述べるが, FCV 用の水素需要を与えることで，そ れを賄うように改質器の運用手法が決定される。FCV 用の 水素需要が多いと, 本来の燃料電池用の水素が $\mathrm{FCV}$ 用に 回されるため不足してしまい，燃料電池の設備利用率が低下 すると考えられる。そこで, FCV 用水素需要量をパラメー夕 
として計算を行い, 需要家ごとに燃料電池の設備利用率が 低下しない範囲での, つまり燃料電池本来の利用に影響を与 えない範囲での FCV 用水素需要量の上限值を水素製造可能 量として評価することとした。

FCV 用水素需要量は, FCV の市販車である「MIRAI」諸 元表 ${ }^{14)}$ より水素消費率 $0.13 \mathrm{Nm}^{3} / \mathrm{km}$ ， および，パラメータと して設定した年間自動車走行距離を用いて年間の水素需要 量を算出して 365 で割ることにより，1日あたりの水素需要 量とした。またこの水素は毎朝 6:00に一度に充填されると 想定した。本研究では, 年間自動車走行距離のパラメータ を $0 \mathrm{~km}, 8,000 \mathrm{~km}, 12,000 \mathrm{~km}, 16,000 \mathrm{~km}, 20,000 \mathrm{~km}$, $24,000 \mathrm{~km}$ と変えて計算を行い, 燃料電池の本来の運転に 影響を与えない FCV 用水素製造可能量を求めた。

\section{3 計算条件}

\subsection{1 対象システムの設備構成}

本研究では, 燃料電池スタック, 改質器, 貯湯槽, 水素 貯蔵タンク, バックアップ用のガス給湯器で構成されるシス テムを各世帯が所有することを想定した。本研究の対象とし た設備とエネルギーや水素, 都市ガスのフローを Fig. 1 に示 す。電力需要に対しては系統電力および然料電池から, 給 湯需要に対しては燃料電池の排熱が蓄えられた貯湯槽とバッ クアップ用ガス給湯器から供給されるものとした。改質器に よって都市ガスから水素が製造されて水素貯蔵タンクに蓄え られ，燃料電池や FCV 用燃料として活用される。通常の燃 料電池において, 然料電池スタックに余剩に供給された水 素は, 改質器に戻されて改質のための反応熱として利用され ている。本研究では, 燃料電池スタックでの発電に用いる

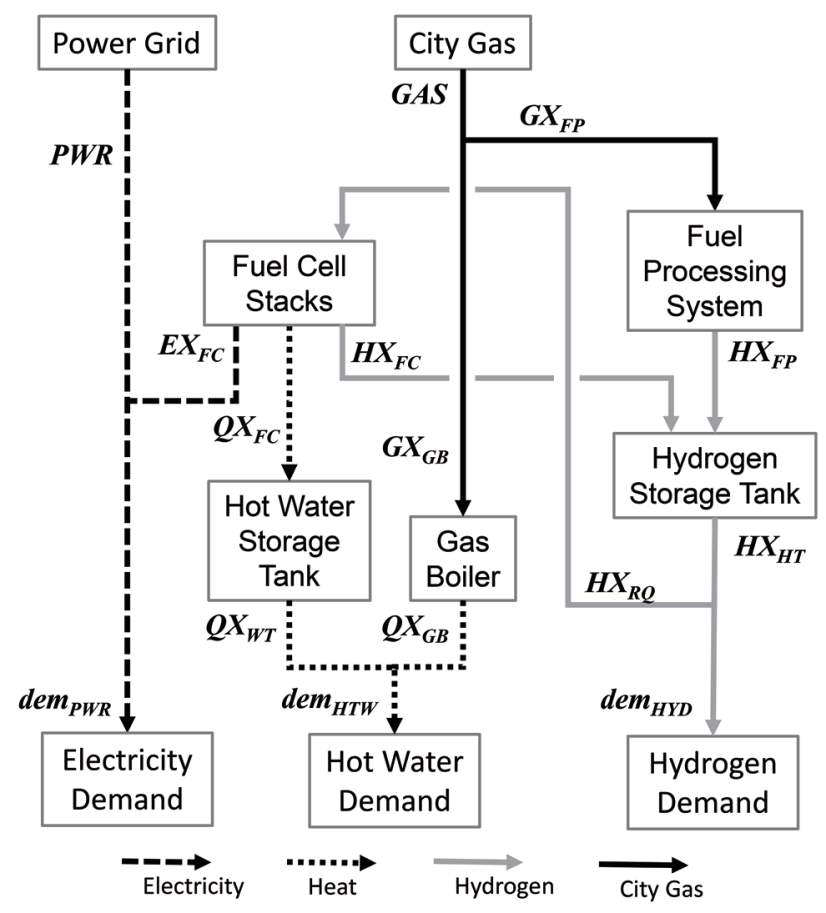

Fig. 1 Schematic diagram of energy flows
以外の水素をできるだけ FCV 用の燃料として活用することを 想定するため, 燃料電池スタックに余剰に供給される水素は 水素貯蔵タンクに戻され, 改質のための反応熱は都市ガスに よって供給されるものとした。

燃料電池の定格出力は $0.7 \mathrm{~kW}$ 15) とした。燃料電池スタッ クの発電効率についてはインバー夕効率及び補機損を含めた 部分負荷効率 ${ }^{12)}$ を考慮し, 本研究では簡単のため Fig. 2 に 示す線形で近似した部分負荷時の水素必要量を用いて計算

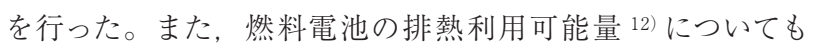
部分負荷効率の影響を受けるため, Fig. 3 に示す線形近似を 用いた。改質器の定格水素製造能力については, 燃料電池の 定格 $0.7 \mathrm{~kW}$ での発電時の水素必要量である $0.56 \mathrm{Nm}^{3} / \mathrm{h}$ と した ${ }^{15)}$ 。改質器についても部分負荷効率 ${ }^{13)}$ を考慮し, Fig. 4 に示す線形近似した都市ガス消費量を用いた。貯湯槽につ いては簡単のため, 季節によらず $44^{\circ} \mathrm{C}$ の温度差で $140 \mathrm{~L}$ 貯

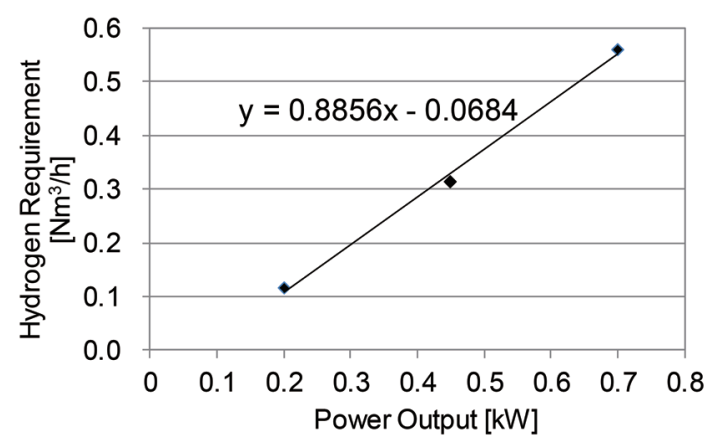

Fig. 2 Hydrogen requirement of fuel cell at partial load

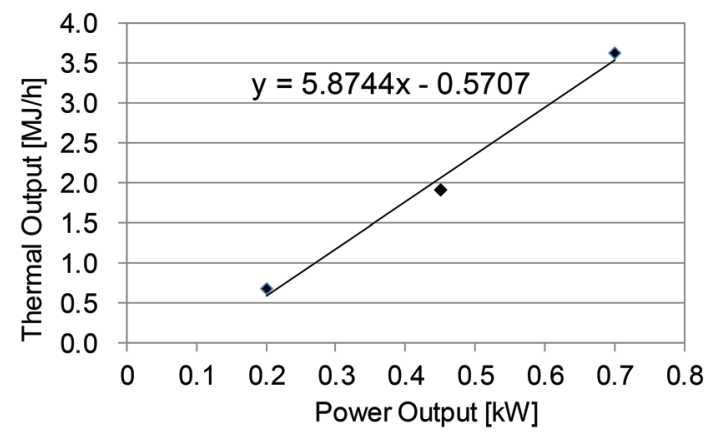

Fig. 3 Thermal output from fuel cell at partial load

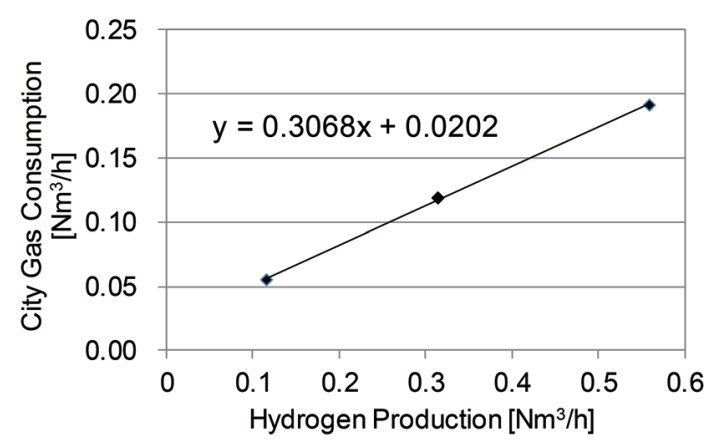

Fig. 4 City gas consumption of FPS at partial load 
湯 ${ }^{15)}$ できると想定して，一律で $25.8 \mathrm{MJ}$ の熱エネルギーを蓄 えられるものとした。なお, 水素貯蔵タンクやバックアップ用 ガス給湯器については，本研究では必要な容量を準備でき るものとした。

なお，固体高分子膜を用いた水素の圧縮・精製技術が研 究されており 16) 19)，民生用への応用が期待される状況にあ るが，本研究ではFCVに水素を充填するための圧縮機は評 価に含めていない。また, 本研究のシステムは, 水素ステー ションが普及するまでの中継ぎ的役割を目的としており，水 素ステーションが少ない状況においては，FCVの初期ユー ザーは燃料充填の利便性を優先して近隣で製造される水素 の利用を選択することを想定している。

\subsection{2 エネルギー需要データ}

本研究では，1～12 月の各月代表日 1 日，計 12 日を計 算対象とし，それぞれの計算結果に各月の日数を乗じること で年間量に換算して評価を行うこととした。エネルギー需要 データとして，東京・神奈川の 24 世帯において計測された電 力消費量およびガス消費量を利用した。この 24 世帯の世帯 人員は 3〜 7人で, 住宅の延床面積は $92 \sim 330 \mathrm{~m}^{2}$ であった。 世帯ごとに各月の電力需要量, 給湯需要量のデータを時刻 別に平均值を算出して代表日として用いた。年間電力消費量 の 24 世带の平均は 9,771 kWh, 最大世帯で 21,058 kWh, 最小世帯で $5,330 \mathrm{kWh}$ であった。需要最大最小世帯および 24 世帯平均の各月毎時の電力消費量を Fig. 5 に示す。また，年 間給湯需要量の 24 世帯平均は 23.4 GJ, 最大世帯で 51.5 GJ, 最小世帯で 10.5 GJであった。貯湯槽を用いたシステムを検 討するため, 給湯需要の日量が運用に影響を与える重要なパ ラメータとなる。需要最大最小世帯拈よび 24 世帯平均の各 月の給湯需要量の日量を Fig. 6 に示す。

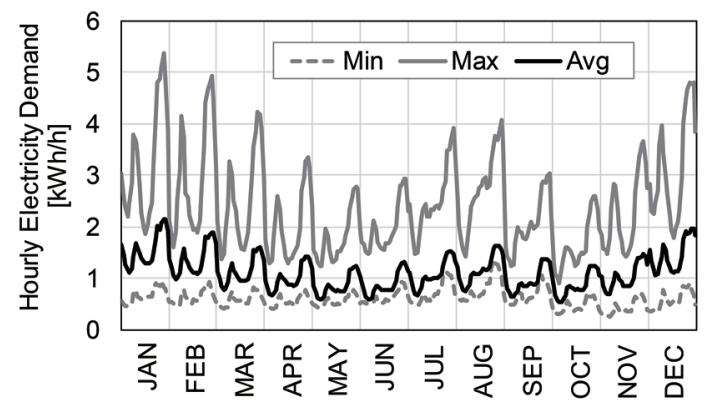

Fig. 5 Hourly electricity demand data and its range

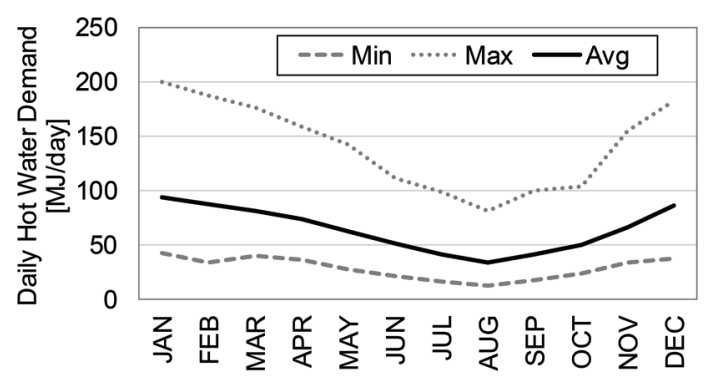

Fig. 6 Daily hot water demand data and its range

\section{3. 改質器・燃料電池の最適運転計画モデル}

\section{1 モデルの定式化}

本研究で作成したモデルは, 混合整数線形計画法 (MILP: Mixed Integer Linear Programming) を用いており，与えら れた各時刻の電力, 給湯, 水素需要を満たしながら, 運転 コストが最小となる燃料電池スタックおよび改質器の独立し た運転スケジュールを決定するものである。

以下に目的関数抒よび制約条件について詳述する。大文 字で始まる変数は決定変数, 小文字で始まる変数は入力デー 夕となる定数である。なお, 決定変数は非負数とした。なお, エネルギー量や都市ガス, 水素の量を表す決定変数につい ては, Fig. 1 中の対応するフローにも合わせて示した。

\section{2 目的関数}

本研究では，固定費は一定として目的関数には固定費は 含めず，式 (1) に示す年間運転コスト $C_{O P R}[$ 円/年 $]$ を目的関 数とした。これが最小となるように, 改質器および燃料電池 スタックの最適な運用方法を決定するものとした。

$$
C_{\text {OPR }}=\sum_{m=1}^{12}\left(\operatorname{days}_{m} \cdot \sum_{t=1}^{24}\left(\operatorname{gcst}_{m, t} \cdot G A S_{m, t}+\text { pcst }_{m, t} \cdot P W R_{m, t}\right)\right)
$$

ここで，添字の $m$ は $1 〜 12$ 月, $t$ は $1 〜 24$ 時を表す。また, days は日数, GAS は都市ガスの消費量 $\left[\mathrm{Nm}^{3}\right], P W R$ は系統 電力から購入する電力量 $[\mathrm{kWh}$, gcst はガス料金単価 [円/ $\mathrm{Nm}^{3}$ ], pcstは電気料金単価 [円 $/ \mathrm{kWh}$ をを表す。本研究で は, 2014 年〜 2015 年までの単価の調査結果より中央值を用

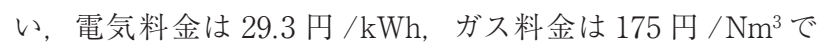
一定とした ${ }^{6)}$ 。

\section{3 制約条件}

電力, 給湯, 水素の需給に関する制約式を以下に示す。

$$
\begin{aligned}
& P W R_{m, t}+E X_{F C, m, t}=\operatorname{dem}_{P W R, m, t} \\
& Q X_{W T, m, t}+Q X_{G B, m, t}=\operatorname{dem}_{H T W, m, t} \\
& H X_{H T, m, t}-H X_{R Q, m, t}=\operatorname{dem}_{H Y D, m, t}
\end{aligned}
$$

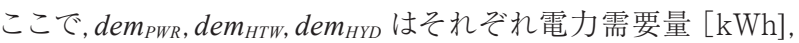
給湯需要量 $[\mathrm{MJ}]$, 水素需要量 $\left[\mathrm{Nm}^{3}\right]$ を表す。 $E X, Q X, H X$ は各設備からの出力量で, それぞれ電力量 $[\mathrm{kWh}]$, 熱量 $[\mathrm{MJ}]$, 水素量 $\left[\mathrm{Nm}^{3}\right]$ を表す。添字は設備を表し, $F C$ は燃 料電池スタック, $W T$ は貯湯槽, $G B$ はバックアップ用ガス給湯 器, は水素貯蔵タンクを意味する。また $H X_{R Q}$ は, 水素貯蔵 タンクから供給される燃料電池スタックが発電時に必要とす る水素量 $\left[\mathrm{Nm}^{3}\right]$ を表す。

貯湯槽内の蓄熱量に関する制約を式 (5)に, 水素貯蔵夕 ンク内の貯蔵量に関する制約を式 (6)に示す。

$$
\begin{aligned}
Q_{m, t} & =(1-l s) \cdot Q_{m, t-1}+Q X_{F C, m, t}-Q X_{W T, m, t} \\
H_{m, t} & =H_{m, t-1}+H X_{F P, m, t}+H X_{F C, m, t}-H X_{H T, m, t}
\end{aligned}
$$

添字の $F P$ は改質器を表し, $Q$ は貯湯槽内の蓄熱量 $[\mathrm{MJ}], H$ は水素貯蔵タンク内の水素貯蔵量 $\left[\mathrm{Nm}^{3}\right]$ を表す。 $Q X_{F C}$ は燃 料電池による発電時の排熱利用量 $[\mathrm{MJ}]$ を, $H X_{F C}$ は使用さ れずに水素貯蔵タンクに戻される余剩の水素量 $\left[\mathrm{Nm}^{3}\right]$ を表す。 ls は1時間あたりの貯湯槽からの放熱口ス率 [-]を表し，本 
研究では 1 日約 $20 \% の$ 放熱口スを想定し $l s=0.01$ とした。

燃料電池スタックの水素必要量 $H X_{R Q}\left[\mathrm{Nm}^{3}\right]$, および, 排 熱利用量 $Q X_{F C}[\mathrm{MJ}]$ は, Fig. 2 および Fig. 3 に示す部分負 荷特性より燃料電池スタックの発電量 $E X_{F C}$ の 1 次式で近似 し，それぞれ式（7）および式（8）の制約条件を加えた。また, 燃料電池スタックでは水素必要量 $H X_{R Q}\left[\mathrm{Nm}^{3}\right]$ の $80 \%$ が消 費され，20\%は余剩水素として水素貯蔵タンクに戻されるも のとした。

$$
\begin{aligned}
& H X_{R Q, m, t}=a h \cdot E X_{F C, m, t}+b h \cdot U_{F C, m, t} \\
& Q X_{F C, m, t}=a q \cdot E X_{F C, m, t}+b q \cdot U_{F C, m, t} \\
& H X_{F C, m, t}=0.2 \cdot H X_{R Q, m, t}
\end{aligned}
$$

ここで $U$ は起動停止を表し，0 または 1 のみを取る（起動時 $=1$, 停止時 $=0 ）$ バイナリ変数である。本研究では係数は, $a h=0.8856, b h=-0.0684, a q=5.8744, b q=-0.5707$ を 用いた。

目的関数で用いた都市ガス消費量 $G A S$ や各設備の都市ガ ス消費量に関しては，以下の制約条件を用いた。

$$
\begin{aligned}
& G A S_{m, t}=G X_{F P, m, t}+G X_{G B, m, t} \\
& G X_{F P, m, t}=a g \cdot H X_{F P, m, t}+\mathrm{bg} \cdot U_{F P, m, t} \\
& G X_{G B, m, t}=\left(1 / \text { ene }_{G A S}\right) \cdot\left(1 / \text { eff }_{G B}\right) \cdot Q X_{G B, m, t}
\end{aligned}
$$

は都市ガス消費量 $\left[\mathrm{Nm}^{3}\right]$ を表し, 式 (11) は改質器の, 式 (12) はバックアップ用ガス給湯器による消費量に関する式であ る。改質器の都市ガス使用量は, 部分負荷効率を考慮して Fig. 4 で示した線形近似式を用い, $a g=0.3068, b g=0.0202$ とした。ガス給湯器の都市ガス消費量は, ガス給湯器の効 率を $e f f_{G B}=0.95^{11)}$, 都市ガスの発熱量を ene $_{G A S}=45[\mathrm{MJ} /$ $\mathrm{Nm}^{3}$ ]として求めた。

各設備の出力量や蓄熱量, 水素貯蔵量の上下限制約とし て，式（13）～式（16）を用いた。

$$
\begin{aligned}
& \min _{F C} \cdot U_{F C, m, t} \leq E X_{F C, m, t} \leq \max _{F C} \cdot U_{F C, m, t} \\
& \min _{F P} \cdot U_{F P, m, t} \leq H X_{F P, m, t} \leq \max _{F P} \cdot U_{F P, m, t} \\
& 0 \leq Q_{m, t} \leq \operatorname{cap}_{W T} \\
& 0 \leq H_{m, t} \leq \operatorname{cap}_{H T}
\end{aligned}
$$

ここで $\max , \min$ はそれぞれ 1 時間あたりの最大, 最小出力 量を表し, 燃料電池に関してはそれぞれ $0.7,0.2 \mathrm{kWh}$, 改 質器に関しては $0.56,0.12 \mathrm{Nm}^{3}$ とした ${ }^{15)}$ 。また，貯湯槽の 熱容量 $\operatorname{cap}_{W T}$ は $25.8 \mathrm{MJ}$ とし, 水素貯蔵タンクの貯蔵容量 $\operatorname{cap}_{H T}$ については本研究では上限を設けなかった。

本研究では，運転開始および運転終了を示す 0 または 1 をとる決定変数 $A$ および $B$ を式 (17) 〜式 (19) を用いて定義 し，燃料電池スタックを起動できる回数は式 (20)により1日 に1回のみとした。また式 (21)により, 燃料電池スタックの 1 日の運転時間は最大で 22 時間 ${ }^{15)}$ とした。

$$
\begin{aligned}
& U_{F C, m, t}-U_{F C, m, t-1}=A_{F C, m, t}-B_{F C, m, t} \\
& A_{F C, m, t} \leq U_{F C, m, t} \\
& B_{F C, m, t} \leq 1-U_{F C, m, t} \\
& \sum_{t=1}^{24} A_{F C, m, t} \leq 1 \\
& \sum_{t=1}^{24} U_{F C, m, t} \leq 22
\end{aligned}
$$

本研究では各月の代表日を用いた年間の評価を行うため, 熱や水素の製造量が過大や過小にならないよう，1日ごとに 熱や水素の製造量と放熱等によるロス, 需要量がバランスし ている必要がある。各月の代表日の計算に拈いて, 貯湯槽 内の蓄熱量, 水素貯蔵タンク内の水素貯蔵量, および, 燃 料電池の起動状態に関して, 周期境界条件を用いることと し，以下の条件を加えた。

$$
Q_{m, 0}=Q_{m, 24}, H_{m, 0}=H_{m, 24}, U_{F C, m, 0}=U_{F C, m, 24}
$$

\section{FCV 用水素製造可能量の評価結果}

\section{1 モデルによる燃料電池・改質器の運用結果}

24 世帯の需要データのうち, 年間給湯需要量が関東地方 の戸建住宅の平均に近い $22.4 \mathrm{GJ} /$ year である世帯 X に関し てシミュレーションした8月の結果を例として Fig. 7 に示す。 （a）には燃料電池による発電量，（b）には改質器による水素 製造量，（c）には貯湯槽内の蓄熱量を示した。比較のため, 提案するシステムを用いた年間 $1,040 \mathrm{Nm}^{3}$ (8,000 $\mathrm{km}$ 走行分) の FCV 用水素需要がある場合の計算結果だけでなく, 既存 の燃料電池スタックと改質器が同負荷率で運転されるシステ

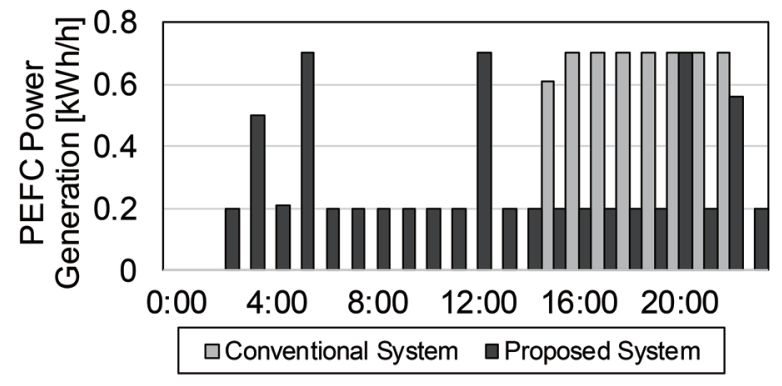

(a) PEFC power generation

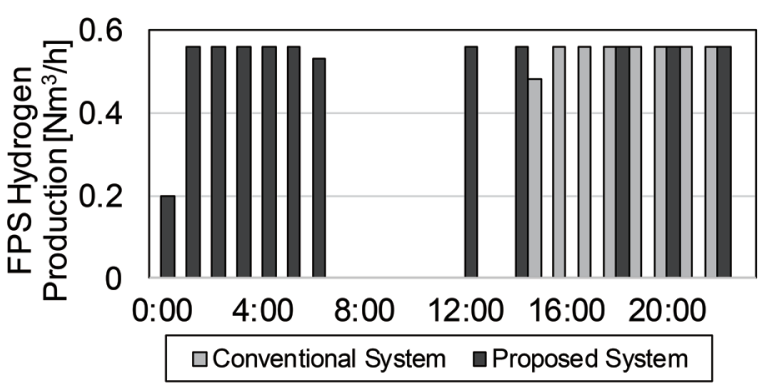

(b) FPS hydrogen production

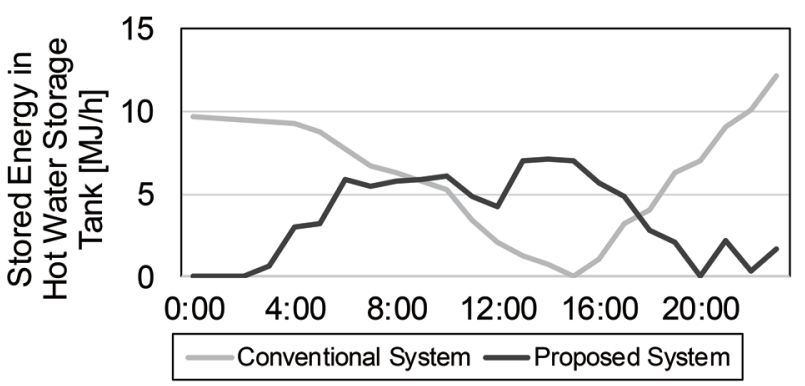

(c) Stored energy in the hot water storage tank

Fig. 7 Simulation results in August 
ムによる FCV 用水素需要がない場合の結果も合わせて示し た。

既存のシステムでは燃料電池は, スタック効率と改質器効 率を合わせた総合効率が高い高負荷率での運転が行われ， 改質器と燃料電池は連動して 15 時から 23 時に運転されて いる。一方, 提案するシステムでは, 燃料電池の運転は大部 分が効率の良い低負荷で行われ，改質器は FCV 用水素需 要のため運転時間が延びているが，運転時にはこれまで通 り効率の良い高負荷率での運転が行われていることが分か る。改質器の運転量の増加から余力を用いて FCV 用の水素 製造が行われていることも確認できる。既存のシステムとは 異なり, 早朝から夜にかけて1日を通して燃料電池を運転し ており，貯湯槽への蓄熱パターンも大きく変化していること が分かる。

世帯ごとの余力を用いた水素製造可能量を評価するた め, FCV 用水素需要量を, $0 \mathrm{~km}, 8,000 \mathrm{~km}, 12,000 \mathrm{~km}$, $16,000 \mathrm{~km}, 20,000 \mathrm{~km}, 24,000 \mathrm{~km}$ 走行分と変えて計算を 行った。それぞれの計算結果より燃料電池と改質器の設備利 用率を算出した。世帯 Xの例を Fig. 8 に示す。水素需要量 を大きくするにつれて改質器の設備利用率は増加しており, 燃 料電池の設備利用率は, $0 \mathrm{~km}$ の場合と比較すると $16,000 \mathrm{~km}$ 走行分以上の水素需要量で低下していることが分かる。水 素需要量が $0 \mathrm{~km}$ の場合は, 燃料電池は本来の目的である 給湯需要を賄うための運転を最大限行い，不足分はガス給 湯器により供給されている。一方, 水素需要量が増加すると, 燃料電池で用いる水素が不足して燃料電池の稼働率が低下 し, ガス給湯器による熱供給量が増加する。そこで, 燃料 電池の稼働率が低下しない範囲を燃料電池本来の運転に影 響を与えていない状況と考え, そのときの最大水素製造量を 水素製造可能量とした。Fig. 8 で示した世帯 Xについては, 余力を用いた水素製造可能量は $12,000 \mathrm{~km}$ 走行分であるこ とが分かった。

\section{2 世帯による水素製造可能量の分布}

24 世帯すべてに関して計算を行い, FCV 用水素製造可能 量の計算結果とその世帯の年間給湯需要量を比較した結果 を Fig. 9 に示す。給湯需要量が多い世帯では燃料電池の本

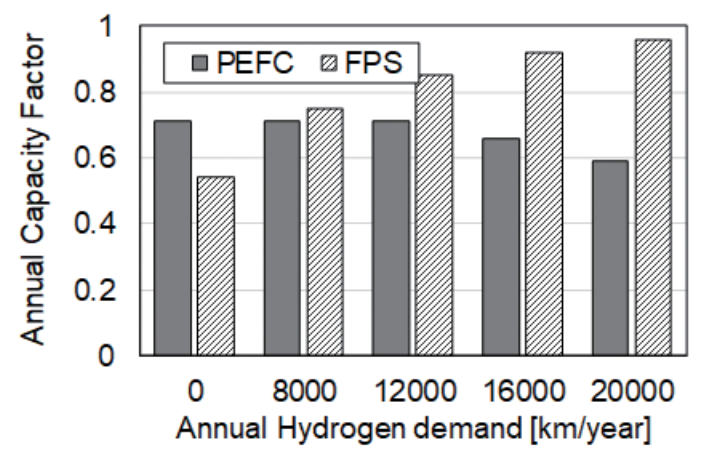

Fig. 8 Annual capacity factors of the PEFC and the FPS by hydrogen demand for the FCV

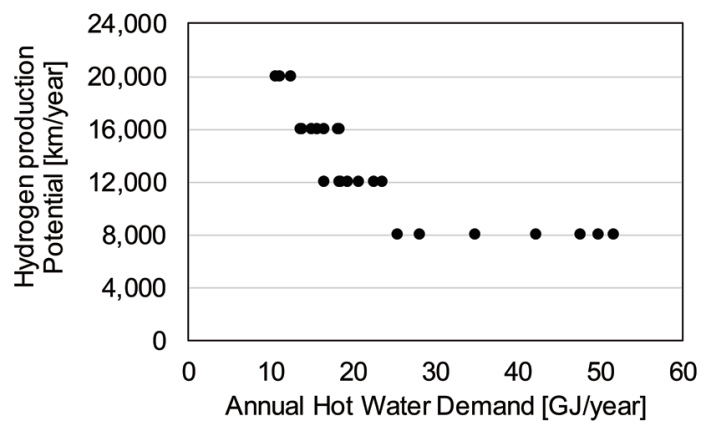

Fig. 9 Relation between hydrogen production potential and annual hot water demand

来の利用による設備利用率が高いため, FCV 用水素製造余 力が少ないことが見て取れるが，24 世帯すべてにおいて少な くとも年間 8,000 km 走行分の水素 $1,040 \mathrm{Nm}^{3}$ を製造可能で あり，世帯によっては最大で 2,600 $\mathrm{Nm}^{3}$ (20,000 km 走行分) の水素を製造可能であることが分かった。1台あたりの自家 用普通車の年間走行距離は全国平均で $8,000 \mathrm{~km}$ 程度であ る20)ことを考えると，1世帯あたり1台の FCV のための燃 料を家庭用燃料電池で自家生産可能であると言える。

提案したシステムでは, 改質器は多くの時間において最大 の改質効率となる負荷率で運転され，24 世帯の計算結果よ り, $1 \mathrm{Nm}^{3}$ の水素の製造にかかる都市ガス消費量は 0.33 $0.36 \mathrm{Nm}^{3}$ であり, 水素製造にかかるランニングコストは 58.0 〜 62.7 円 $/ \mathrm{Nm}^{3}$ となった。

\section{5. 多摩地域を対象とした水素供給可能範囲の分析}

\section{1 分析目的}

家庭用燃料電池を用いた FCV 用水素製造可能量の分析 により，1世帯あたりの水素製造可能量を求めた。その結果 を用いると, 提案するシステムを集合住宅の全世帯に導入し た場合の水素製造可能量から, 地域内の FCVのどの程度 の割合の水素需要を満たすことができるかを評価することが でき, 集合住宅に導入した本システムの FCV 用水素ステー ションとしての可能性を検討した。

\section{2 対象地域の集合住宅と水素需要量の設定}

東京都の多摩地域の市町村のうち, 都市計画区域ごとの 市街化区域の面積割合が $70 \%$ を回る, 立川市, 武蔵野市, 三鷹市, 府中市, 昭島市, 調布市, 町田市, 小金井市, 小 平市, 日野市, 東村山市, 国分寺市, 国立市, 狛江市, 東 大和市, 清瀬市, 東久留米市, 武蔵村山市, 多摩市, 稲城市, 西東京市の計 21 市 $401 \mathrm{~km}^{2}$ を供給対象地域とした。

本研究では, 建築後 30 年を経過した共同住宅の建て替え による燃料電池を用いた給湯システムへの転換を想定し, 水 素ステーションの設置を検討する集合住宅は, 住宅地図デー タベースより対象地域の 100 世帯以上の集合住宅の中から, 2020 年時点で築 30 年以上となる 159 の集合住宅を対象とし た。4 章の結果より, 少なくとも FCV 8,000 km 分の水素は どの世帯でも余力で製造可能であることから, 簡単のため 1 


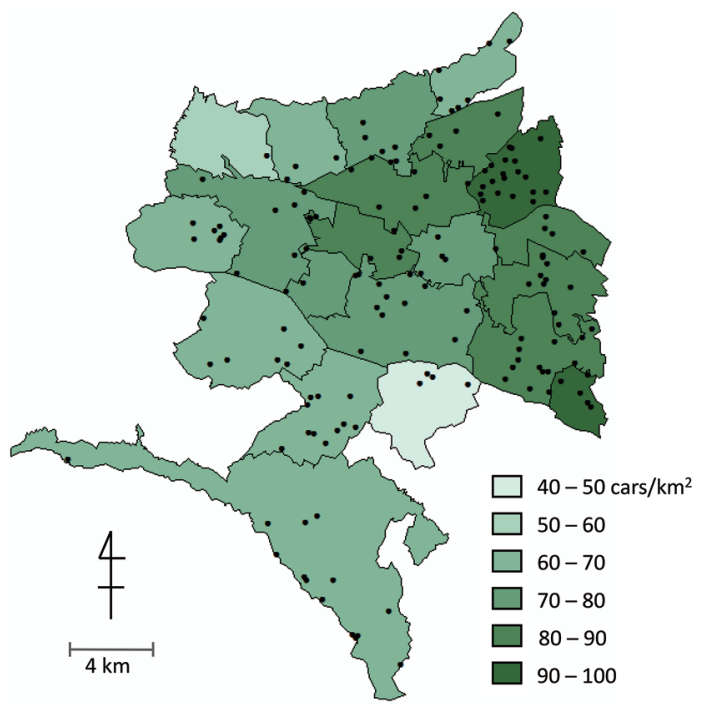

Fig. 10 Average penetration density of FCV in each city and positions of target collective housings

世帯あたり 8,000 km 分, $1,040 \mathrm{Nm}^{3}$ の水素を製造できるも のとした。4 章の戸建住宅における結果を集合住宅に適用し ているが，一般に集合住宅は戸建住宅よりエネルギー消費 量が小さいため, 余力で水素を製造できる能力は集合住宅 の方が高くなると考えられる。そのため, 集合住宅において も 8,000 km 分の水素はどの世帯でも製造可能であるとした。

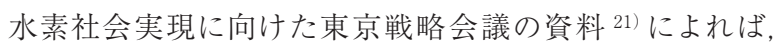
2025 年に東京全体で 10 万台という FCV の普及目標が掲げ られている。これは現在の東京都の総乗用車数 ${ }^{22)}$ の $3.75 \%$ にあたり，東京都内で均等に FCV が普及するとして，対象 地域には28,464 台の FCV が普及すると想定した。1台あた りの年間走行距離は, 自動車燃料消費量統計 20) より東京都 における自動車 1 台あたりの年間平均走行距離を算出し, 1 台あたり $5,121 \mathrm{~km}$ とした。これにより対象地域 $1 \mathrm{~km}^{2}$ あた り平均で $363,544 \mathrm{~km}$ 走行分の水素需要があるものとした。 対象とした集合住宅の位置と, 各自治体別の FCV 普及密度 の算出結果を Fig. 10 に示す。密度が最大の自治体は, 西 東京市の 99.8 台 $/ \mathrm{km}^{2}$ で, 最小の自治体である稲城市の 46.5 台 $/ \mathrm{km}^{2}$ の 2 倍程度の開きがあった。この普及密度を 5.4 節の水素供給可能範囲の評価に用いた。

\section{3 導入する集合住宅の選択方法}

対象とした集合住宅のうち, 以下の方法で本システムを統 合した水素ステーションを導入する集合住宅を決定した。

まず，世帯数の最も多い集合住宅に導入することとし，水 素製造可能量と水素需要の関係から供給可能範囲を円で描 いた。その円の内側の集合住宅には導入しないものとし, 円 の外側のうち最も世帯数が多い集合住宅を次の導入地点とし た。順に導入箇所を増やしていき, 30 ヶ所まで導入順序を 決定した。決定した 30 ケ所の集合住宅位置および描いた円 をFig. 11 に示す。濃く塗ったエリアは，世帯数が多い上位 10 ケ所の円に含まれるエリアである。

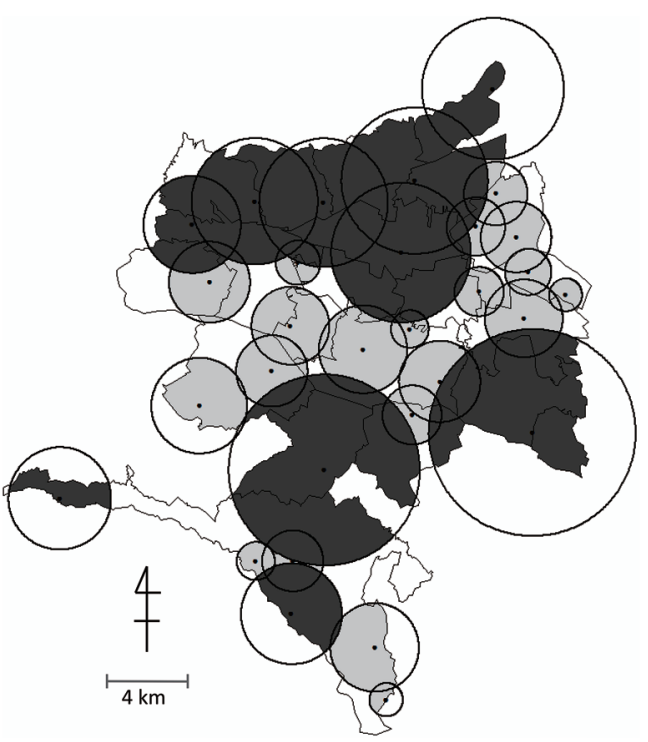

Fig. 11 Location of selected 30 collective housings and circles of supply ability of each collective housing

\section{4 水素供給可能範囲の評価方法とその結果}

描いた円を用いて，導入する集合住宅数を 5，10，15， 20，25，30 ケ所としたそれぞれの場合について, 対象地域 と円の重なり部分（Fig. 11の色が塗られた部分）の面積を 求め, 対象地域全体に占める面積カバー率を求めた。

対象地域外を含むことや円同士の重なりがあること，ま た，地域ごとに FCVの普及密度が異なることから，面積力 バー率は，供給できる FCVの台数カバー率とは一致しない。 そこで，それぞれの集合住宅が最も近くなるエリアをボロノ イ分割により求め, それぞれの範囲内の水素需要量に対して, 集合住宅の水素ステーションが供給できる水素量の割合をエ リアごとに算出した。100\%を超えるエリアは $100 \%$ とした。

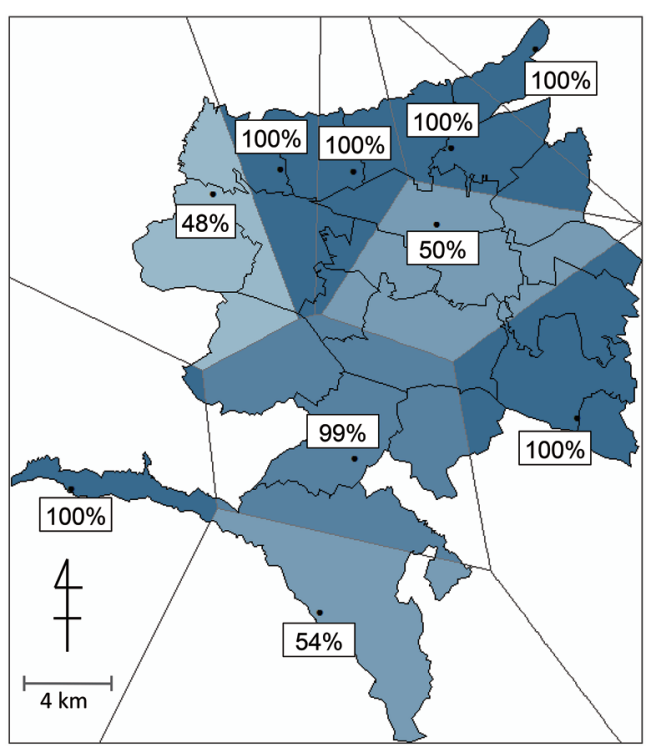

Fig. 12 FCV cover ratio by each voronoi area in case of 10 hydrogen stations 
Table 1 Supply area cover ration and FCV cover ratio

\begin{tabular}{c|c|c}
\hline Number of Stations & $\begin{array}{c}\text { Area Cover Ratio } \\
\text { by Circles }\end{array}$ & $\begin{array}{c}\text { FCV Cover Ratio } \\
\text { by Voronoi Diagram }\end{array}$ \\
\hline 5 & $42.4 \%$ & $56.3 \%$ \\
\hline 10 & $59.0 \%$ & $80.9 \%$ \\
\hline 15 & $71.9 \%$ & $81.6 \%$ \\
\hline 20 & $81.5 \%$ & $79.6 \%$ \\
\hline 25 & $83.9 \%$ & $78.2 \%$ \\
\hline 30 & $85.8 \%$ & $77.7 \%$ \\
\hline
\end{tabular}

集合住宅が 10 ヶ所の場合の自治体別の FCV 台数カバー率 をFig. 12 に示す。対象地域全体の FCV 台数カバー率は, 80.9\%であった。集合住宅数を 5，10，15，20，25，30 ケ 所としたそれぞれの場合, 面積カバー率および FCV 台数カ バー率をTable 1 に示す。

15 ケ所の集合住宅を水素ステーションとした場合が FCV の台数カバー率が最大となり, 集合住宅数をさらに増やすと, 水素供給量の少ない集合住宅による水素ステーションが増え るため, 最寄りの水素ステーションの水素供給量では不足す る FCV が増加し，FCV カバー率は低下していくことが分か る。集合住宅数が 10 ケ所の場合ですでに FCV カバー率は $80 \%$ を超えており, 10 ヶ所程度であっても余力の水素製造 能力を用いた本システムを導入した集合住宅により，水素ス テーションの役割の一部を担うことができると考えられる。

\section{6. 結 言}

本論文では，家庭用燃料電池に付属の改質器の余力を活 用した FCV 用水素製造システムを提案した。多様な給湯負 荷を持つ 24 世帯を対象としたエネルギー需給シミュレーショ ンを行い, 燃料電池本来の給湯機能に影響を与えない範囲 での FCV 用水素製造可能量を定量的に評価した。

シミュレーション結果より，24 世帯すべてにおいて少なく とも年間 8,000 $\mathrm{km}$ 走行分の水素製造が可能であり，世帯に よっては最大で $20,000 \mathrm{~km}$ 走行分の水素を製造可能である ことが分かった。平均的な自動車の年間走行距離に対する FCV 用の水素は本システムで賄うことができることが示され た。

また，本システムを各家庭に導入した集合住宅が水素ス テーションの代替となる可能性を, 東京都多摩地区を対象 として評価した。多摩地区内の 10 ヶ所の集合住宅に本シ ステムを導入した場合， 2025 年の FCV の普及目標に対して 80.9\%の FCV の水素需要を満たすことができることが示さ れた。

以上より, 提案したシステムは, 水素ステーションの導入 が拡大するまでの中継ぎ的な役割として十分に期待できる。 今後の課題として, 水素充填用圧縮機を含む提案したシステ ムの初期コストも考慮した経済性の評価が必要である。

\section{文 献: References}

1) Ministry of Council for a Strategy for Hydrogen and Fuel Cells, http://www.meti.go.jp/press/2015/03/2016 0322009/20160322009-c.pdf (Last access: 2017.3.4)：水 素 ·燃料電池戦略協議会, http://www.meti.go.jp/press/ 2015/03/20160322009/20160322009-c.pdf (Last access: 2017.3.4)

2) Tomioka, H., JARI Research Journal, JRJ20130806, 1-5 (2013)：富岡秀徳, JARI Research Journal, 20130806, 1-5 (2013)

3) Oomori, K.; Kuwano, T.; Kojima, N., Hydrogen Energy System, 30(2), 41-45 (2005): 大盛幹土, 久和野敏明, 児 島伸之，水素エネルギーシステム，30(2), 41-45 (2005)

4) Fuel Cell Commercialization Conference of Japan, http://fccj.jp/hystation/ (Last access: 2017.3.4)：燃 料 電池実用化推進協議会, http://fccj.jp/hystation/ (Last access: 2017.3.4)

5) Maeda, K.; Masumoto, K.; Hayato, A., J. Power Sources, 195, 3779-3784 (2010)

6) Ito, H., Int. J. Hydrogen Energy, 41(34), 15111-15123 (2016)

7) Aoki, T.; Habara, H.; Shimoda, Y., Journal of Japan Society of Energy and Resources, 37, 9-11 (2015): 青木拓也, 羽原宏美, 下田吉之, エネルギー・資源学会論文誌, 37, 9-11 (2015)

8) Wakui, T.; Wada, N.; Yokoyama, R., Energy Convers. Manage., 77 40-51 (2014)

9) Aki, H.; Yamamoto, S.; Kondoh, J.; Maeda, T.; Yamaguchi, H.; Murata, A.; Ishii, I., Int. J. Hydrogen Energy, 31(8), 967-980 (2006)

10) Aki, H.; Taniguchi, Y.; Tamura, I.; Kegasa, A.; Hayakawa, H.; Ishikawa, Y.; Yamamoto, S.; Sugimoto, I., Int. J. Hydrogen Energy, 37(2), 1204-1213 (2012)

11) Kobayashi, K., Hydrogen Energy System, 36(3), 51-54 (2011)：小林広介，水素エネルギーシステム, 36(3), 51-54 (2011)

12) Wallmark, C.; Alvfors, P., J. Power Sources, 106, 83-92 (2002)

13) Aki, H.; Kondoh, J.; Ishii, I.; Yamamoto, S., Proc. of the 19th Conference on Energy, Economy, and Environment, 1-3, 1-6 (2003) : 安芸裕久, 近藤潤次, 石井格, 山本重, 第 19 回エネルギーシステム・経済・環境コンファレンス講 演論文集，1-3, 1-6 (2003)

14) Toyota Motor Corporation, Specification table of Toyota MIRAI, http://toyota.jp/pages/contents/mirai/001_ p_001/pdf/spec/mirai_spec_201508.pdf (Last access: 2017.3.4) : トヨ夕自動車株式会社, トヨ夕 MIRAI 主要 諸 元 表, http://toyota.jp/pages/contents/mirai/001_ p_001/pdf/spec/mirai_spec_201508.pdf (Last access: 2017.3.4)

15) Tokyo Gas Co., Ltd., Specifications of ENE FARM, 
http://home.tokyo-gas.co.jp/enefarm_special/enefarm/ specific.html (Last access: 2017.3.4)：東京ガス株式会 社, エネファーム製品仕様, http://home.tokyo-gas.co.jp/ enefarm_special/enefarm/specific.html (Last access: 2017.3.4)

16) Rohland, B.; Eberle, K.; Ströbel, R.; Scholta, J.; Garche, J., Electrochim. Acta, 43(24), 3841-3846 (1998)

17) Strobel, R.; Oszcipok, M.; Fasil, M., J. Power Sources, 105, 208-215 (2002)

18) Casati, C.; Longhi, P.; Zanderighi, L.; Bianchi, F., J. Power Sources, 180, 103-113 (2008)

19) Grigoriev, S. A.; Shtatniy, I. G.; Millet, P.; Porembsky, V. I.; Fateev, V. N., Int. J. Hydrogen Energy, 36(6), 4148-4155 (2011)

20) Ministry of Land, Infrastructure, Transport and Tourism, Statistical Yearbook on Motor Vehicle Fuel
Consumption (2015) : 国土交通省, 自動車燃料消費量統 計年報 平成 27 年度 第 9 表 (2015)

21) Tokyo Strategic Council for the Realization of a hydrogen Society, http://www.kankyo.metro. tokyo.jp/energy/hydrogen/26torimatome.pdf (Last access: 2016.10.12) : 水素社会実現に向けた東京戦略 会 議, http://www.kankyo.metro.tokyo.jp/energy/ hydrogen/26torimatome.pdf (Last access: 2016.10.12).

22) Statistics Division, Bureau of General Affair, Tokyo Metropolitan Government, Tokyo Statistical Yearbook, http://www.toukei.metro.tokyo.jp/tnenkan/2014/ tn14qa040600.xls (Last access: 2017.3.24) : 東京都総務 局統計部, 東京都統計年鑑, http://www.toukei.metro. tokyo.jp/tnenkan/2014/tn14qa040600.xls (Last access: 2017.3.24) 